\title{
Połączenia lutowane aluminium z miedzią, stalą niestopową i stopową, wykonane spoiwami cynkowymi
}

\section{Soldered joints aluminum with copper, unalloyed steel and alloy steel made of zinc binders}

\section{Streszczenie}

Wykonywanie połączeń lutowanych aluminium $z$ innymi metalami, takimi jak: miedź, stal niestopowa i stopowa, związane jest z dużymi trudnościami. Problemy te wynikają głównie ze zróżnicowanych właściwości fizykochemicznych i mechanicznych spajanych materiałów. Ponadto występuje niebezpieczeństwo tworzenia się twardych faz międzymetalicznych powodujących kruchość połączeń lutowanych.

W artykule przedstawiono wyniki prób zwilżalności i rozpływności badanych materiałów spoiwami cynkowymi. Przeprowadzono również badania metalograficzne przy użyciu mikroskopii świetlnej oraz pomiary mikrotwardości i wytrzymałości na ścinanie połączeń lutowanych.

\section{Wstęp}

Aluminium i jego stopy są materiałami coraz częściej stosowanymi w połączeniach spajanych. Wynika to przede wszystkim z ich dobrej przewodności elektrycznej i cieplnej oraz niewielkiego ciężaru właściwe-

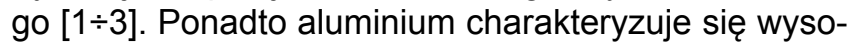
ką odpornością na korozję atmosferyczną oraz dobrą odpornością chemiczną na działanie wodoru, tlenu, siarki, chloru, bromu i fluoru [4].

Lutowanie jest jednak często bardzo trudne $z$ uwagi na zróżnicowane właściwości fizykochemiczne spajanych materiałów. Niska temperatura topnienia aluminium (ok. $660^{\circ} \mathrm{C}$ ) oraz pokrywająca jego powierzchnię szczelna warstwa trudnotopliwych tlenków $\mathrm{Al}_{2} \mathrm{O}_{3}$

Prof. dr hab. inż. Zbigniew Mirski, mgr inż. Tomasz Wojdat - Politechnika Wrocławska. (ok. $2050^{\circ} \mathrm{C}$ ) sprawiają, że jest ono znacznie trudniej lutowanym materiałem niż miedź, stal niestopowa i stopowa [2]. Z tego też względu materiały dodatkowe do lutowania $z$ innymi metalami, tj. luty i topniki, dobiera się przede wszystkim do lutowania aluminium. Może to jednak powodować problemy związane ze zwilżalnością i rozpływnością tych lutów na powierzchni miedzi i stali, a w konsekwencji prowadzić do niewłaściwego wypełnienia szczeliny lutowniczej ciekłym lutem, co powoduje pogorszenie jakości połączeń lutowanych [1, 2].

Użyte w badaniach luty cynkowe ze względu na dużą rozpuszczalność aluminium w cynku (układ równowagi fazowej $\mathrm{Zn}-\mathrm{Al}$ ), sięgającą $83,1 \%$ wag. Al, determinują ich dobrą zwilżalność i rozpływność na powierzchni aluminium. Istnieje jednak niebezpieczeństwo niedostatecznego zwilżania spoiwami cynkowymi powierzchni pozostałych materiałów stosowanych $w$ badaniach, wynikające $z$ braku tworzenia się roztworów stałych z pierwiastkami tych metali, co z kolei sprzyja powstawaniu faz międzymetalicznych 
Tablica I. Skład chemiczny, temperatura topnienia oraz postać stosowanych lutów cynkowych [1, 2]

Table I. The chemical composition, melting point and the form of used zinc solders [1, 2]

\begin{tabular}{|c|c|c|c|c|}
\hline \multirow{2}{*}{$\begin{array}{c}\text { Oznaczenie } \\
\text { lutu }\end{array}$} & \multicolumn{2}{|c|}{ Skład chemiczny, \% wag. } & \multirow{2}{*}{ Zakres temp. topnienia, ${ }^{\circ} \mathrm{C}$} \\
\cline { 2 - 4 } L-ZnAl2 & 98 & 2 & $382 \div 407$ & $382 \div 387$ \\
\hline L-ZnAl4 & 96 & 4 & drut $\varnothing 1,6$ \\
\hline L-ZnAl15 & 85 & 15 & $382 \div 450$ & drut $\varnothing 1,6$ \\
\hline
\end{tabular}

powodujących znaczne obniżenie właściwości mechanicznych połączeń lutowanych.

$\mathrm{Na}$ podstawie obserwacji mikroskopowych oraz pomiarów mikrotwardości złączy lutowanych można wnioskować o pojawieniu się faz międzymetalicznych na granicy połączenia lutów cynkowych z materiałami lutowanymi $z$ aluminium. Tego rodzaju badania umożliwiają określenie szerokości strefy reakcyjnej. Z kolei pomiary mikrotwardości umożliwiają ocenę plastyczności i funkcjonalności połączeń lutowanych. Przyjmuje się, że wraz ze wzrostem twardości strefy reakcyjnej wzrasta kruchość połączeń lutowanych, a co za tym idzie - zmniejszają się ich właściwości mechaniczne.

\section{Materiały stosowane w badaniach}

Do prób lutowania zastosowano luty cynkowe $z$ dodatkiem aluminium, którego zawartość w stopie zwykle nie przekracza $15 \%$ wag. [1, 2]. Skład chemiczny, temperaturę topnienia oraz postać stosowanych lutów Zn-Al przedstawiono w tablicy I. Oznaczenia lutów podane $w$ tej tablicy są jedynie oznaczeniami skrótowymi i nie są zgodne z normą. Według normy PN EN ISO 3677:2007 oznaczenie np. dla lutu cynkowego o zawartości $4 \%$ wag. Al to S-Zn96Al4 [5].

Lutowanie aluminium wymaga stosowania dodatkowo aktywnych topników, opartych głównie na bazie chlorków litu, cyny, cynku i cezu, zdolnych do usunięcia trudno zwilżalnej lutami warstwy tlenków $\mathrm{Al}_{2} \mathrm{O}_{3}$ $[2,3]$. Topniki na bazie litu, cyny i cynku są przeważnie topnikami korozyjnymi powodującymi erozję złącza lutowanego w przypadku niedokładnego usunięcia ich pozostałości po przeprowadzonym procesie lutowania. Żeby tego uniknąć, do prób lutowania wybrano niekorozyjny topnik o handlowej nazwie 192 NX firmy Castolin, zawierający związki cezu, w postaci pasty. Temperatura aktywności topnika 192 NX mieści się w zakresie $420 \div 470^{\circ} \mathrm{C}$ [12].

Jako materiału podstawowego do badań użyto aluminium EN AW-1050A wg PN-EN 573-3:2010 o składzie chemicznym podanym w tablicy II [6]. Aluminium EN AW-1050A stosowane jest w przemyśle energetycznym, budownictwie, przemyśle chemicznym i spożywczym, do produkcji przedmiotów gospodarstwa domowego, opakowań itp. [7].

Do lutowania miękkiego $\mathrm{z}$ aluminium wybrano $[8 \div 10]$ :

- miedź M1E (wg PN-77/H-82120) w stanie miękkim - 60 HBW 2,5/62,5. Miedź M1E zawiera: 99,90\% wag. $\mathrm{Cu}$ i ogółem $0,1 \%$ dopuszczalnych zanieczyszczeń, w tym $0,001 \%$ wag. $\mathrm{Bi}$ i $0,005 \%$ wag. $\mathrm{Pb}$;

- stal niestopową DC01 (wg PN-EN10130:2009) zawierającą: $0,12 \%$ wag. $\mathrm{C}$ oraz $0,60 \%$ wag. $\mathrm{Mn}$, $0,045 \%$ wag. $P$ i $0,045 \%$ wag. S, reszta $\mathrm{Fe}$;

- stal kwasoodporną X5CrNi18-10 (wg PN-EN 10088:2007) zawierającą: $\leq 0,07 \%$ wag. C, $\leq 1,0 \%$ wag. $\mathrm{Si}, \leq 2,0 \%$ wag. $\mathrm{Mn}, 0,045 \%$ wag. $\mathrm{P}, \leq 0,015 \%$ wag. S, $\leq 0,11 \%$ wag. $\mathrm{N}, 17,5 \div 19,5 \%$ wag. Cr oraz $8,0 \div 10,5 \%$ wag. $\mathrm{Ni}$, reszta $\mathrm{Fe}$.

\section{Zwilżalność i rozpływność lutów cynkowych na badanych podłożach}

Próby zwilżalności i rozpływności lutów Zn-Al przeprowadzono na blaszkach o grubości $0,5 \mathrm{~mm}$ i powierzchni $50 \times 50 \mathrm{~mm}$. Do prób stosowano luty o masie $0,1 \mathrm{~g}$ pocięte na odcinki o długości ok. $1 \mathrm{~mm}$, które następnie pokryto topnikiem o masie równej połowie masy lutu. Bezpośrednio przed próbami podłoża lutowane oczyszczono papierem ściernym o ozn. 400 i odtłuszczono rozpuszczalnikiem Nitro.

Próby zwilżalności i rozpływności przeprowadzono przez nagrzewanie próbek płomieniem propropanowo-powietrznym przy użyciu palnika Bunsena. Próbki umieszczono na siatce pokrytej ceramiką ułożoną na trójnogu i podgrzewano płomieniem od dołu. Od momentu stopienia lutu czas nagrzewania wynosił ok. $5 \mathrm{~s}$ [2].

W pomiarach rozpływności do obliczania pól powierzchni rozpłynięcia się lutów użyto programu optycznego DP - Soft Olympus do obróbki cyfrowej zdjęć z funkcją planimetrowania powierzchni. Wyniki pomiarów rozpływności lutów Zn-Al na powierzchni badanych metali przedstawiono $\mathrm{w}$ tablicy III oraz na rysunku 1. Są to wartości średnie z pięciu pomiarów.

Tablica II. Skład chemiczny aluminium EN AW - 1050A [6]

Table II. The chemical composition of aluminum grade EN AW-1050A [6]

\begin{tabular}{|c|c|c|c|c|c|c|c|c|c|c|c|}
\hline \multicolumn{3}{|c|}{ Oznaczenie } & \multicolumn{10}{|c|}{ Skład chemiczny, \% wag. } \\
\hline PN & EN & Al min & Fe max & Si max & Zn max & Ti max & Mg max & Mn max & Cu max & Ni max & Inne max \\
\hline A1 & EN AW - 1050A & 99,5 & 0,40 & 0,25 & 0,07 & 0,05 & 0,05 & 0,05 & 0,05 & 0,05 & 0,03 \\
\hline
\end{tabular}


Niezależnie od rodzaju podłoża, na którym przeprowadzono próby, widoczny jest wzrost pól powierzchni rozpływności lutów cynkowych, rosnący wraz ze wzrostem zawartości aluminium w lucie.

Po dokonaniu pomiarów rozpływności lutów Zn-Al na powierzchni badanych metali, zmierzono kąty zwilżalności. W tym celu próbki przecięto w połowie rozpłyniętej kropli lutu i przygotowano zgłady metalograficzne. Sfotografowano je i na tej podstawie określono

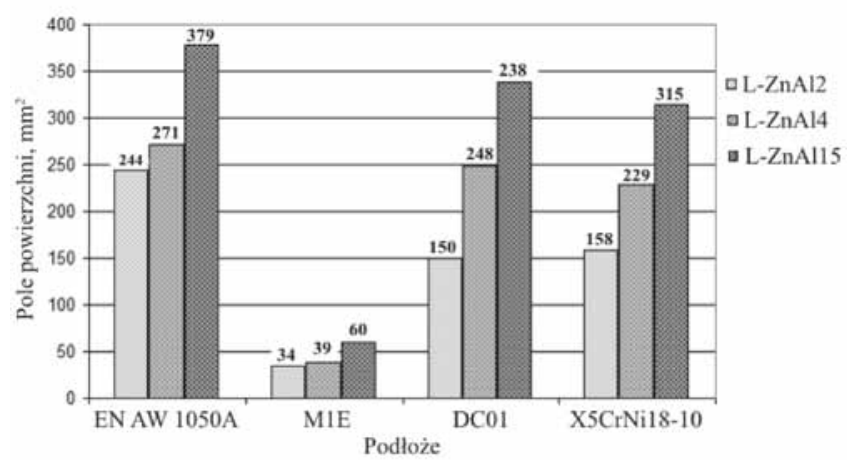

Rys. 1. Wyniki próby rozpływności lutów cynkowych na powierzchni badanych metali

Fig. 1. The results of tests surface area of melt zinc solders on the surface of tested metals

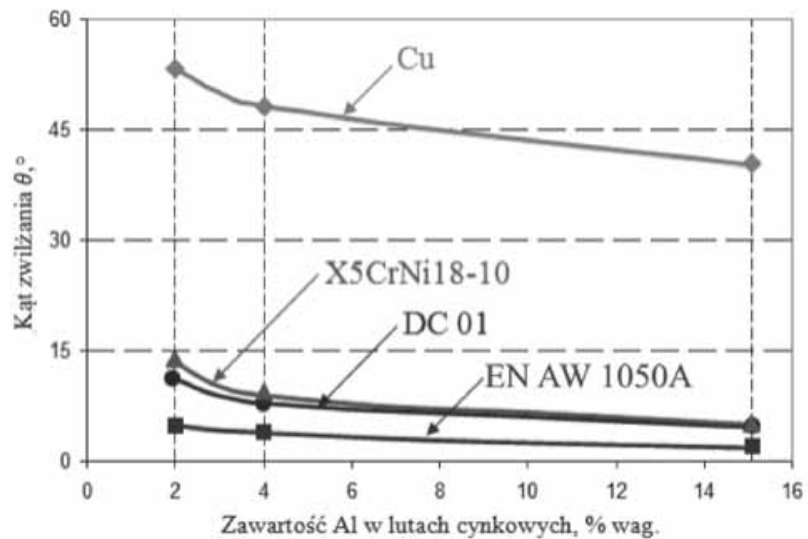

Rys. 2. Wpływ zawartości aluminium w lutach cynkowych na zwilżalność badanych podłoży

Fig. 2. The impact of content aluminum in zinc solders on tested substrates wettability graficznie kąty zwilżania, których wartości zamieszczono $w$ tablicy IV. Są to również wartości średnie z pięciu pomiarów.

Rosnąca zawartość Al w lutach cynkowych wpływa również na poprawę zwilżalności badanych podłoży, niezależnie od ich rodzaju, o czym świadczą malejące wartości kątów zwilżania $\theta$ (rys. 2). Zwilżalność aluminium oraz stali niestopowej i kwasoodpornej lutami cynkowymi jest bardzo dobra. Wartość kąta zwilżania w żadnym z przypadków nie przekracza $15^{\circ}$. Znacznie gorsza sytuacja występuje w przypadku podłoża miedzianego, które nie jest zwilżane spoiwami cynkowymi w sposób zadowalający, co może powodować problemy podczas wykonywania połączeń $\mathrm{Al}-\mathrm{Cu}$.

\section{Badania metalograficzne i pomiary mikrotwardości}

Często stosowane, zwłaszcza $\mathrm{w}$ budowie urządzeń chłodniczych, są połączenia rurkowe aluminium z miedzią (rys. 3a). Na rysunku 3 pokazano złącze, w którym w rurkę aluminiową o średnicy $8,0 \times 0,9 \mathrm{~mm}$ wlutowano rurkę miedzianą o średnicy $6,0 \times 1,0 \mathrm{~mm}$. Poprawne wykonanie tego typu połączenia przez lutowanie płomieniowe jest $w$ praktyce bardzo trudne. Jest to związane z ograniczoną zwilżalnością miedzi spoiwami cynkowymi, która powoduje znaczne wydłużenie czasu lutowania. Dłuższy czas lutowania powoduje bowiem roztwarzanie aluminiowej rurki o grubości ścianki $0,9 \mathrm{~mm}$ przez spoiwa cynkowe (rys. 3b).

$Z$ połączeń rurkowych pokazanych na rysunku $3 a$ odcięto złącze lutowane, które następnie przecięto wzdłuż średnicy i przygotowano zgłady metalograficzne. Na rysunku 4 pokazano przekrój poprzeczny złącza lutowanego Al-Cu wykonanego przy użyciu lutu L-ZnAl4. Zaznaczono miejsca niewypełnione lutem, stanowiące poważne zagrożenie dla poprawnego funkcjonowania złącza, głównie dla jego szczelności. Podobna sytuacja występuje w przypadku połączeń wykonanych przy użyciu pozostałych dwóch lutów

Tablica III. Wyniki prób rozpływności lutów cynkowych na powierzchni badanych metali

Table III. The results of tests surface area of melt zinc solders on the surface of tested metals

\begin{tabular}{|c|c|c|c|c|c|}
\hline \multirow{2}{*}{ Lut } & \multirow{2}{*}{ Topnik } & \multicolumn{3}{|c|}{ Pole powierzchni rozpłynięcia się lutu, mm ${ }^{2}$} \\
\cline { 3 - 5 } & & aluminium EN AW-1050A & miedź M1E & stal niestopowa DC01 & stal stopowa X5CrNi18-10 \\
\hline \multirow{2}{*}{$192 \mathrm{NX}$} & 244 & 34 & 150 & 248 \\
\cline { 3 - 5 } & & 271 & 39 & 229 \\
\cline { 3 - 6 } & & 379 & 60 & 338 \\
\hline
\end{tabular}

Tablica IV. Wyniki pomiarów zwilżalności lutów cynkowych na badanych podłożach

Table IV. The results of wettability measurements zinc solders on tested substrates

\begin{tabular}{|c|c|c|c|c|c|}
\hline \multirow{2}{*}{ Lut } & \multirow{2}{*}{ Topnik } & \multicolumn{4}{|c|}{ Kąt zwilżania, ${ }^{\circ}$} \\
\cline { 4 - 6 } & & aluminium EN AW-1050A & miedź M1E & stal niestopowa DC01 & stal stopowa X5CrNi18-10 \\
\hline \multirow{2}{*}{ L-ZnAl2 } & 52 NX & 4 & 59 & 13 & 9 \\
\cline { 4 - 6 } & & 2 & 52 & 14 \\
\hline
\end{tabular}




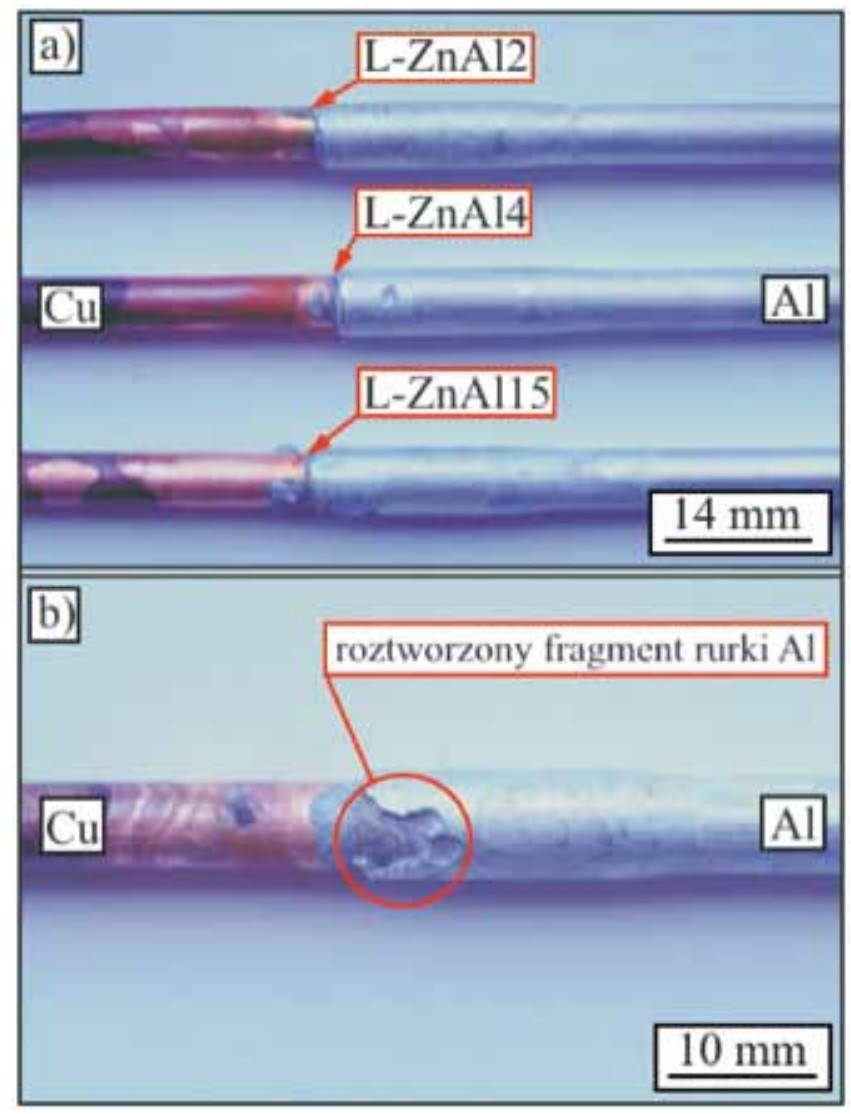

Rys. 3. Połączenia rurkowe $\mathrm{Al}-\mathrm{Cu}$ wykonane lutami cynkowymi (a) i roztworzony fragment rurki (b)

Fig. 3. Pipe joints Al-Cu made by zinc solders (a) and digest part of pipe (b)

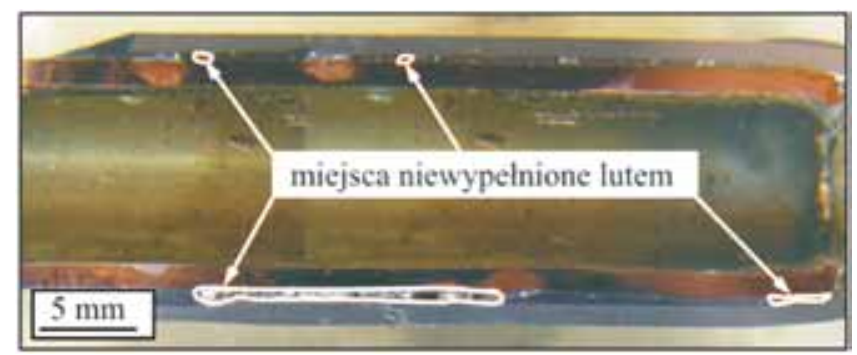

Rys. 4. Makrostruktura połączenia lutowanego $\mathrm{Al}-\mathrm{Cu}$ wykonanego przy użyciu lutu L-ZnAl4

Fig. 4. Macrostructure soldering joint $\mathrm{Al}-\mathrm{Cu}$ made using $\mathrm{L}-\mathrm{ZnAl} 4$ solder

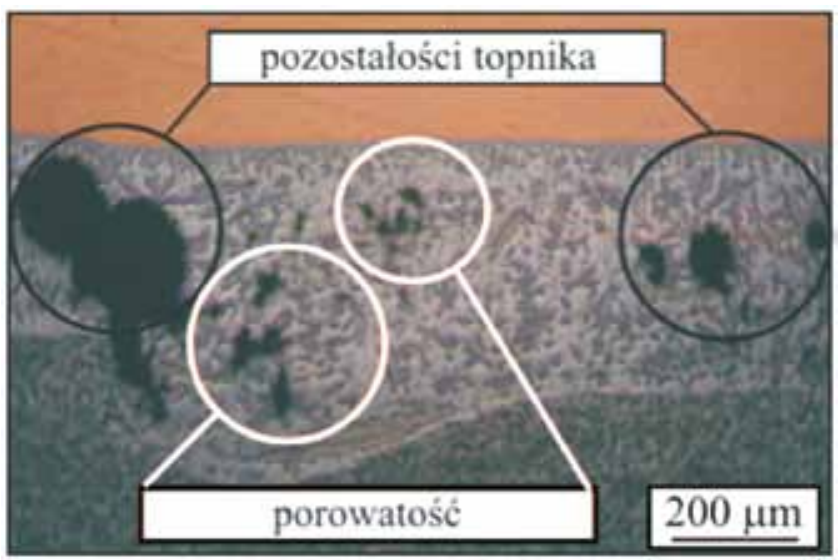

Rys. 5. Niezgodności lutownicze w połączeniu rurkowym $\mathrm{Al}-\mathrm{Cu}$ wykonanym przy użyciu lutu L-ZnAl4

Fig. 5. Soldering unconformity in tube joint type Al-Cu made using L-ZnAl4 solder cynkowych: L-ZnAl2 i L-ZnAl15. Jest to prawdopodobnie spowodowane niedostateczną zwilżalnością miedzi spoiwami cynkowymi.

W miejscach wypełnionych lutem stwierdzono również wiele innych niezgodności lutowniczych w lutowinie, takich jak np.: porowatość czy wtrącenia topnikowe (rys. 5).

Wykonano również połączenia zakładkowe $\mathrm{Al}-\mathrm{Cu}$, Al-DC01 oraz Al-X5CrNi18-10, których przekroje pokazano na rysunku 6 . We wszystkich przypadkach na całej długości złącza szczelina lutownicza o szerokości 0,2 mm została wypełniona lutem. Szerokość szczeliny ustalono przy użyciu stalowych drucików dystansowych.

Obserwacjom poddano przede wszystkim strefę pomiędzy lutowiną a lutowanymi materiałami. Na rysunku 7 przedstawiono mikrostruktury połączeń Al-DC01 wykonanych odpowiednio lutami: L-ZnAl2 (a), L-ZnAl4 (b) i L-ZnAl15 (c).

Analizując wyniki badań mikroskopowych, zauważyć można, że wraz ze wzrostem zawartości aluminium w lutach cynkowych wzrasta wielkość ziaren w lutowinie. Może mieć to bezpośredni wpływ na właściwości wytrzymałościowe uzyskanych połączeń lutowanych. Podobna sytuacja ma miejsce także w przypadku połączeń Al-Cu oraz $\mathrm{Al}-\mathrm{X} 5 \mathrm{CrNi18-10.}$

Na przekrojach poprzecznych połączeń lutowanych pokazanych na rysunku 6 dokonano również pomiarów mikrotwardości HV0,025. Pomiary przeprowadzono zgodnie z normą PN-EN ISO 6507-1:2007 Metale - Pomiar twardości sposobem Vickersa - Część 1: Metoda badań. Na rysunku 8 pokazano rozkład mikrotwardości w złączach lutowanych z aluminium.

Badania metalograficzne wykazały, że podczas wykonywania połączeń lutowanych z aluminium, na skutek oddziaływania lutu cynkowego, powierzchnia aluminium ulega roztwarzaniu. Na granicy połączenia

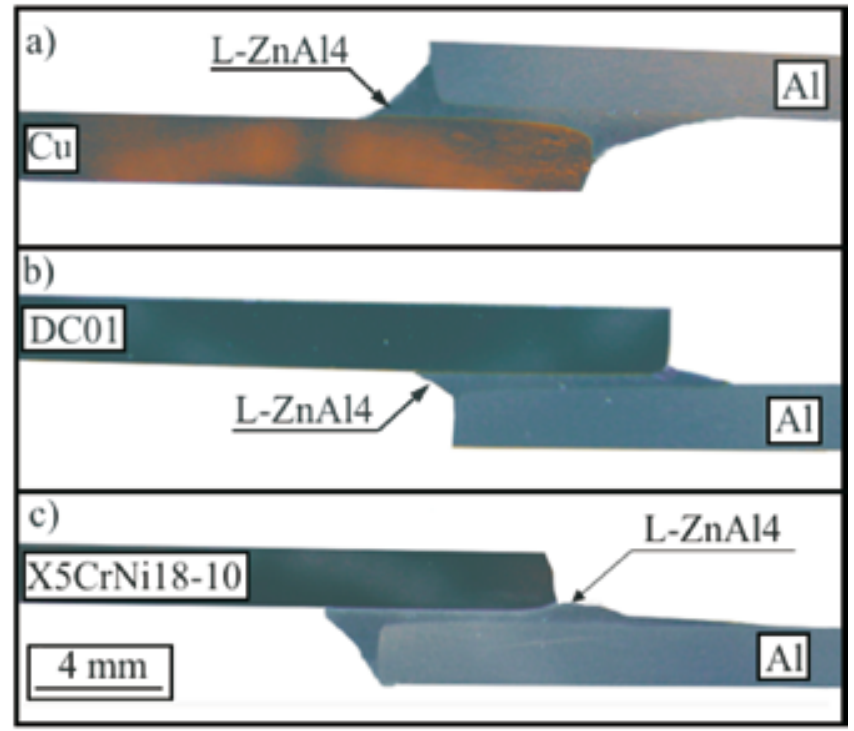

Rys. 6. Złącza zakładkowe: a) Al-Cu, b) Al-DC01, c) Al-X5CrNi18-10, wykonane lutem L-ZnAl4

Fig. 6. Muff joints: a) Al-Cu, b) Al-DC01, c) Al-X5CrNi18-10, made using L-ZnAl4 solder 

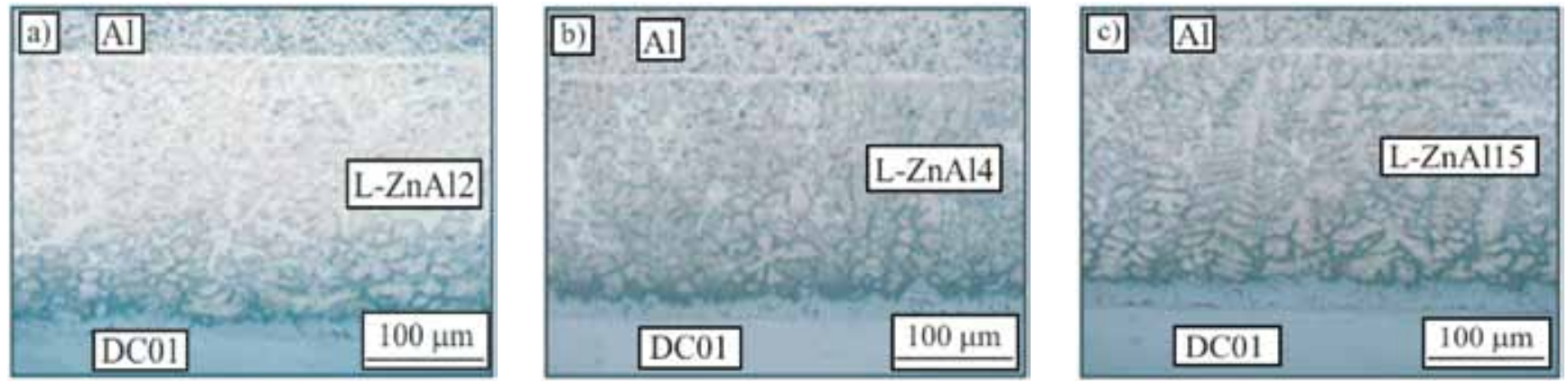

Rys. 7. Mikrostruktura połączeń Al-DC01 wykonanych lutami: L-ZnAl2 (a), L-ZnAl4 (b) i L-ZnAl15 (c), w stanie nietrawionym

Fig. 7. The microstructure of the joints type Al-DC01 made by solders: L-ZnAl2 (a), L-ZnAl4 (b) and L-ZnAl15 (c), able to not digest
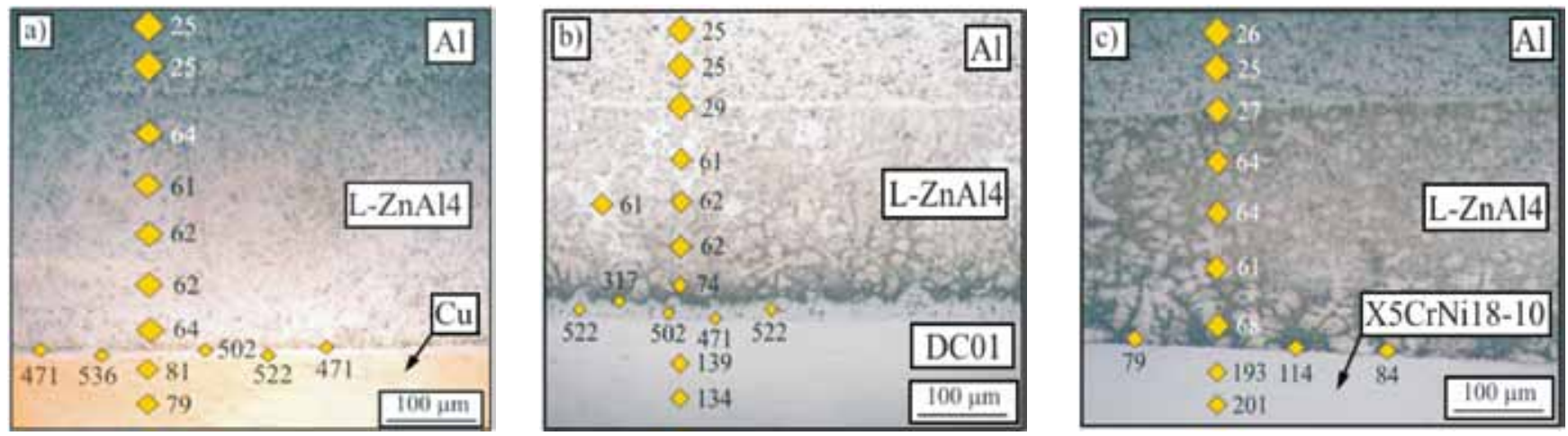

Rys. 8. Rozkład mikrotwardości HV0,025 w złączach Al-Cu (a), Al-DC01 (b) i Al-X5CrNi18-10 (c), wykonanych lutem L-ZnAl4

Fig. 8. The distribution of microhardness HV 0,025 in joints Al-Cu (a), Al-DC01 (b) and Al-X5CrNi18-10 (c), made by L-ZnAl4 solder

lutowiny na osnowie Zn z miedzią M1E oraz stalą niestopową DC01 powstaje w lutowinie stosunkowo twarda strefa reakcyjna o szerokości odpowiednio $7 \div 14 \mu \mathrm{m}$ i $12 \div 21 \mu \mathrm{m}$, mogąca powodować kruchość połączeń lutowanych. Twardość strefy reakcyjnej na granicy połączenia lutów $\mathrm{Zn} z$ miedzią M1E mieści się $w$ zakresie $471 \div 536$ HV 0,025 , a na granicy ze stalą niestopową w zakresie $317 \div 522 \mathrm{HV0} 025$. Strefę reakcyjną mogą stanowić fazy międzymetaliczne z układu: $\mathrm{Al}-\mathrm{Cu}$ i Al-Fe [11]. Identyfikacja faz wymaga jednak przeprowadzenia analizy XRD metodą dyfrakcji rentgenowskiej.

Na granicy połączenia lutów ze stalą kwasoodporną X5CrNi18-10 nie stwierdzono występowania strefy reakcyjnej.

\section{Statyczna próba ścinania połączeń różnoimiennych}

Do statycznej próby ścinania złączy lutowanych przygotowano próbki przedstawione na rysunku 9. Złącza wykonano przez nagrzewanie płomieniem propanowo-powietrznym, przy użyciu lutów L-ZnAl2, L-ZnAl4 i L-ZnAl15.

Szerokość zakładki wynosiła 5,0 mm, złącza ścinano w uchwycie $z$ wkładkami dystansowymi, przy użyciu maszyny wytrzymałościowej firmy Instron, model 3369. Prędkość przesuwu belki poprzecznej maszyny wynosiła $0,2 \mathrm{~cm} / \mathrm{min}$, a zakres obciążeń do $50 \mathrm{kN}$. Wykonano trzy rodzaje różnoimiennych połączeń lutowanych: Al-Cu, Al-DC01 oraz Al-X5CrNi18-10 - po pięć próbek dla każdego rodzaju lutu.

Połączenia $\mathrm{Al}-\mathrm{Cu}$ charakteryzowały się stosunkowo małą wytrzymałością na ścinanie. W żadnym z przypadków niezależnie od zastosowanego rodzaju lutu wytrzymałość połączeń Al-Cu nie przekraczała $30 \mathrm{MPa}$. Charakter złomu po przeprowadzonych próbach wskazywał na zniszczenie adhezyjne złącza od strony miedzi (oderwanie się lutu od miedzi) (rys. 10). Jest to spowodowane występowaniem faz międzymetalicznych na granicy połączenia miedzi z lutowiną oraz niezadowalającą zwilżalnością miedzi lutami cynkowymi.

Żeby określić wytrzymałość połączeń Al-DC01, należało zmniejszyć o połowę szerokość zakładki, ponieważ przy szerokości zakładki wynoszącej $5,0 \mathrm{~mm}$ zerwanie połączenia następowało w strefie wpływu ciepła w aluminium (rys. 11). W wyniku termicznego oddziaływania płomienia propanowo-powietrznego podczas lutowania nastąpił $25 \%$ spadek wytrzymałości na rozciąganie aluminium EN-AW 1050A z ok. $100 \mathrm{MPa}$ do $75 \mathrm{MPa}$.

Zmniejszenie o połowę szerokości zakładki pozwoliło na określenie wytrzymałości połączeń lutowanych Al-DC01, których wytrzymałość w zależności od rodzaju zastosowanego lutu mieści się w zakresie $42 \div 50 \mathrm{MPa}$. Jest ona niespełna dwukrotnie większa niż w przypadku połączeń lutowanych $\mathrm{Al}-\mathrm{Cu}$, pomimo 
iż na granicy połączenia lutowiny z obydwoma metalami tworzy się strefa reakcyjna o zbliżonej twardości. Niemal dwukrotnie większa wytrzymałość połączeń Al-DC01 w porównaniu z wytrzymałością połączeń Al-Cu może zatem wynikać ze znacznie lepszych właściwości lutowniczych, takich jak zwilżalność i rozpływność lutów cynkowych na powierzchni stali niestopowej DC01 w porównaniu do zwilżalności i rozpływności lutów Zn na powierzchni miedzi M1E. W przypadku połączeń Al-DC01 charakter złomu

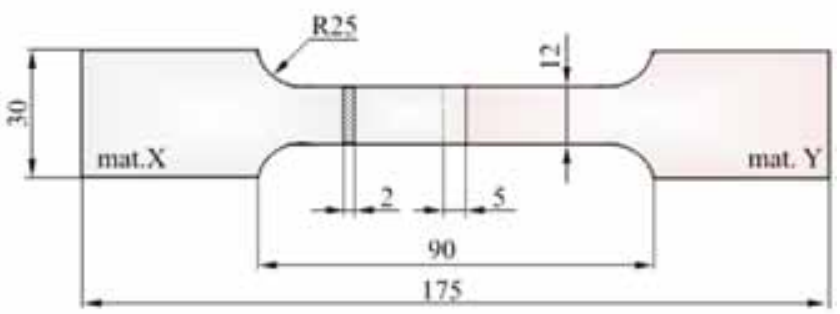

Rys. 9. Kształt i wymiary złącza zakładkowego do statycznej próby ścinania

Fig. 9. The shape and dimensions of the muff joint to the static cutting test

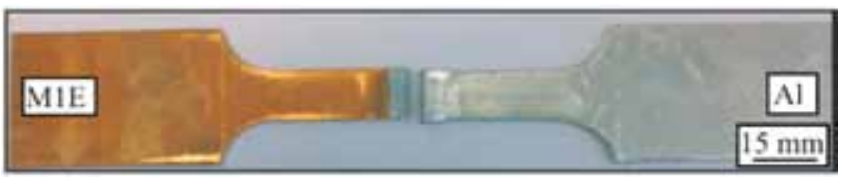

Rys. 10. Przykładowy złom po statycznej próbie ścinania złączy zakładkowych typu Al-L-ZnAl4-Cu

Fig. 10. An example of scrap after static attempt cutting muff joints type Al-L-ZnAl4-Cu

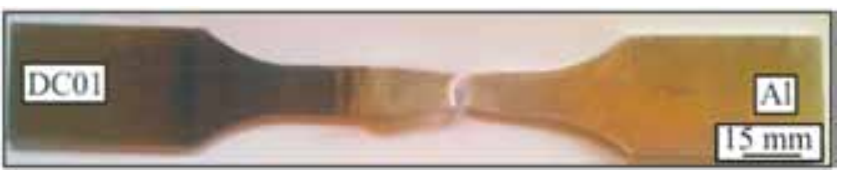

Rys. 11. Zniszczenie złącza zakładkowego Al-DC01 w przypadku zbyt dużej szerokości zakładki wynoszącej 5,0 mm

Fig. 11. The destruction of muff joint Al-DC01 in the case of to much width of the solder slit amount to $5,0 \mathrm{~mm}$

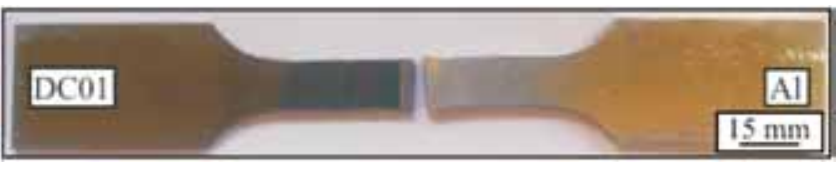

Rys. 12. Przykładowy złom po statycznej próbie ścinania złączy zakładkowych typu Al-L-ZnAl4-DC01

Fig. 12. An example of scrap after static attempt cutting muff joints type Al-L-ZnAl4-DC01

\section{Wnioski}

$\mathrm{Na}$ podstawie analizy wyników przeprowadzonych badań można sformułować następujące wnioski:

- zwilżalność lutami cynkowymi aluminium, stali stopowej i kwasoodpornej jest bardzo dobra, o czym świadczą małe wartości kątów zwilżania nieprzekraczające $15^{\circ}$; otrzymanego po próbach wytrzymałości na ścinanie był również adhezyjny, dekohezja występowała po stronie stali (rys. 12).

W przypadku połączeń $\mathrm{Al}-\mathrm{X} 5 \mathrm{CrNi18-10}$ pomimo zmniejszenia szerokości zakładki o połowę do 2,5 mm nie można było ustalić wytrzymałości złącza lutowanego, ze względu na brak strefy reakcyjnej na granicy połączenia stali kwasoodpornej z lutowiną zerwanie złącza następowało w aluminium w strefie wpływu ciepła. W celu ustalenia wytrzymałości połączenia zmniejszono szerokość zakładki z 2,5 mm do 2,0 mm. W przypadku połączeń wykonanych lutami L-ZnAl2 i L-ZnAl4 wytrzymałość połączeń lutowanych z Al mieściła się w zakresie 52 $\div 58 \mathrm{MPa}$, a zniszczenie złącza miało charakter adhezyjny (rys .13a). Natomiast wytrzymałość połączeń wykonanych przy użyciu lutu L-ZnAl15 wynosiła niespełna $65 \mathrm{MPa}$, a zniszczenie połączenia występowało na skutek dekohezji lutowiny (rys. 13b).

Wyniki statycznej próby ścinania przedstawiono w tablicy V. Są to wartości średnie z 5 pomiarów.

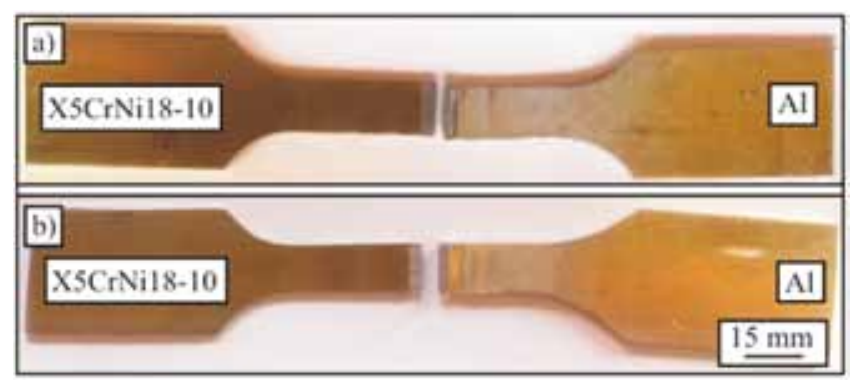

Rys. 13. Przykładowy złom po statycznej próbie ścinania złączy zakładkowych typu Al-L-ZnAl4-X5CrNi18-10 (a) i Al-L-ZnAl15 -X5CrNi18-10 (b)

Fig. 13. An example of scrap after static attempt cutting muff joints type Al-L-ZnAl4-X5CrNi18-10 (a) and Al-L-ZnAl15 -X5CrNi18-10 (b)

Tablica V. Wyniki statycznej próby ścinania złączy zakładkowych, wykonanych przy szerokości szczeliny $0,2 \mathrm{~mm}$

Table V. The results of the static cutting of the opposite muff joints, made with width of solder slit $0,2 \mathrm{~mm}$

\begin{tabular}{|c|c|c|c|}
\hline \multirow{2}{*}{ Lut } & \multicolumn{3}{|c|}{ Wytrzymałość na ścinanie $\mathrm{R}_{\mathrm{t}}, \mathrm{MPa}$} \\
\cline { 2 - 4 } & $\mathrm{Al}-\mathrm{M} 1 \mathrm{E}$ & $\mathrm{Al}-\mathrm{DC01}$ & $\mathrm{Al}-\mathrm{X} 5 \mathrm{CrNi18-10}$ \\
\hline L-ZnAI2 & 22,0 & 41,3 & 52,4 \\
\hline L-ZnAl4 & 24,6 & 44,8 & 57,8 \\
\hline L-ZnAl15 & 27,4 & 48,7 & 64,6 \\
\hline
\end{tabular}

- miedź M1E ma ograniczoną zwilżalność lutami cynkowymi, co powoduje problemy z wypełnieniem szczeliny lutowniczej podczas wykonywania rurkowych połączeń typu $\mathrm{Al}-\mathrm{Cu}$;

- wraz ze wzrostem zawartości Al w lutach Zn wzrasta wielkość ziaren w lutowinie; 
- na granicy połączenia lutów cynkowych z miedzią M1E i stalą DC01 tworzą się twarde strefy reakcyjne mogące powodować kruchość połączeń lutowanych;

- wytrzymałość na ścinanie połączeń $\mathrm{Al}-\mathrm{Cu}$ jest niespełna dwukrotnie mniejsza od wytrzymałości połączeń Al-DC01, pomimo iż na granicy połączenia pomiędzy tymi metalami a lutowiną tworzą się strefy reakcyjne o zbliżonej twardości;
- wytrzymałość na ścinanie połączeń $\mathrm{Al}-\mathrm{X} 5 \mathrm{Cr}$ Ni18-10 wykonanych przy użyciu lutu L-ZnAl15 jest największa spośród badanych połączeń, a dekohezja występuje w lutowinie.

\section{Literatura}

[1] Mirski Z., Granat K., Drzeniek H., Piwowarczyk T., Wojdat T.: Lutowanie miękkie aluminium z miedzią, Przegląd Spawalnictwa, nr 11/2009, s. 15-19.

[2] Mirski Z., Granat K., Drzeniek H., Piwowarczyk T., Wojdat T.: Badanie zwilżalności lutów cynkowych na powierzchni aluminium i innych metali, Przegląd Spawalnictwa, nr 9/2010, s. $48-53$.

[3] Pocica A., Nowak A.: Technologia lutowania aluminium z miedzią, Spajanie, nr 1/2005, s. 9-12.

[4] Pilarczyk J.: Poradnik inżyniera, Spawalnictwo, Tom 2, WNT, Warszawa 2005.

[5] PN EN ISO 3677:2007 Spoiwa do lutowania miękkiego, twardego i lutospawania - Oznaczenie.
[6] PN EN 573-3:2010 Aluminium i stopy aluminium - Skład chemiczny i rodzaje wyrobów przerobionych plastycznie-Część 3: Skład chemiczny i rodzaje wyrobów.

[7] www.metale-kolorowe.eu

[8] PN-77/H-82120 Miedź - Gatunki.

[9] PN EN10130:2009 Wyroby płaskie walcowane na zimno ze stali niskowęglowych do obróbki plastycznej na zimno - Warunki techniczne dostawy.

[10]PN EN 10088:2007 Stale odporne na korozję - Część 1: Gatunki stali odpornej na korozję.

[11] Sękowski K., Piaskowski J., Wojtowicz Z.: Atlas struktur znormalizowanych stopów odlewniczych, WNT, Warszawa 1972.

[12] www.castolin.com

\section{Rapid Weld}

\section{Wysokowydajny proces spawania materialów o dużych grubościach}
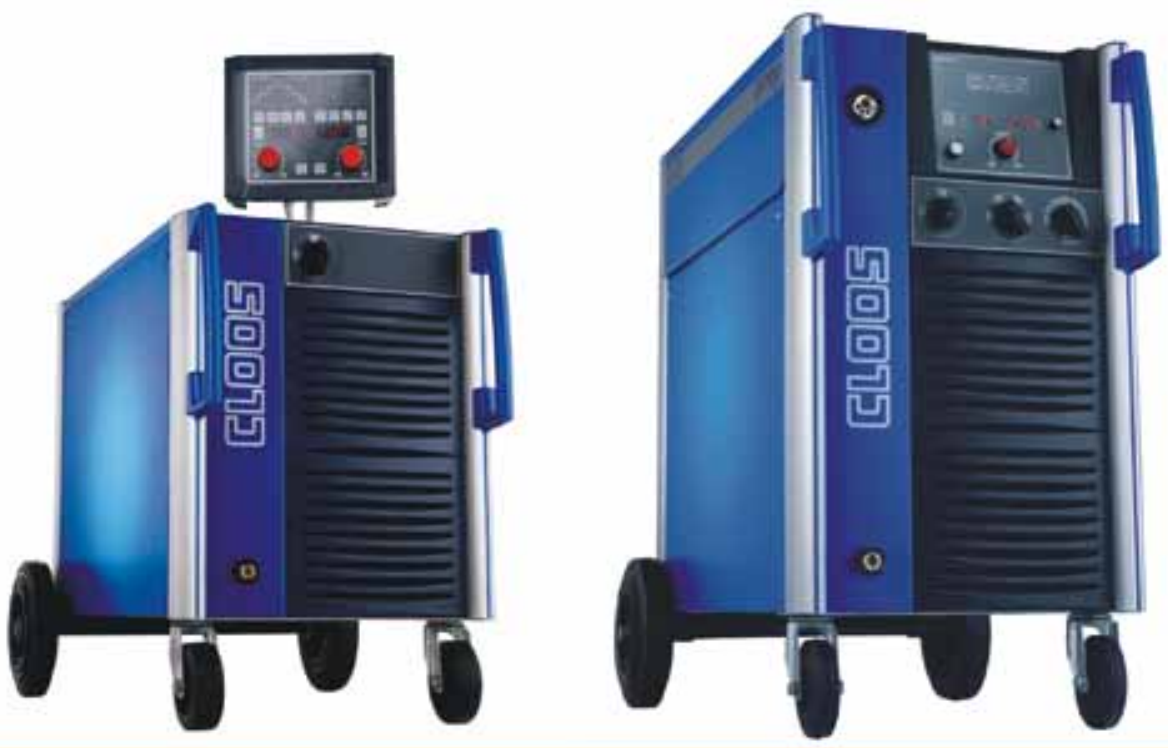

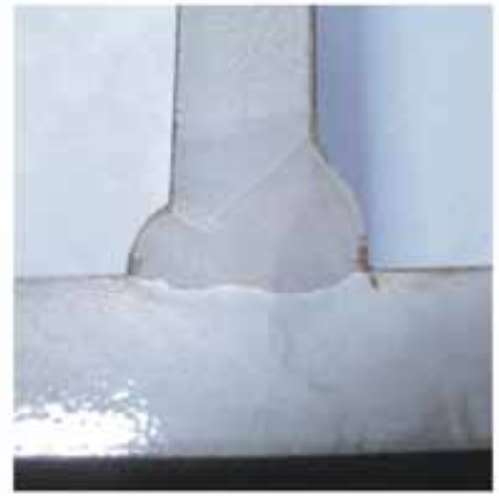

Blachy o grubości 8 i $10 \mathrm{~mm}$ polączone w procesie Rapid Weld

Urzadzenia seril Qineo oferuja szeroka gamę procesów pozwalających na wysokowydajne, powtarzalne I precyzyjne spawanie. Proces Rapid Weld wykorzystywany jest, gdy wymagane są duże wartosci stapiania i optymalne glebokości penetracji, przy wysokich prędkosciach spawania. Jest szczególnie polecany w sektorach, takich jak przemyst cięzkkich konstrukcji stalowych, przemysi stoczniowy i budowa zbiorników.

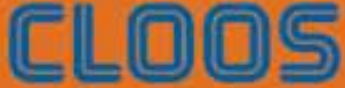

Polska 